\title{
Do Water Bodies Show Better Ecological Status in Natura 2000 Protected Areas Than Non-Protected Ones?-The Case of Greece
}

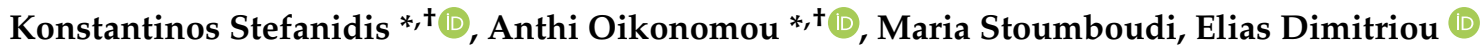 \\ and Nikolaos Theodor Skoulikidis $\mathbb{D}$
}

check for

updates

Citation: Stefanidis, K.; Oikonomou, A.; Stoumboudi, M.; Dimitriou, E.; Skoulikidis, N.T. Do Water Bodies Show Better Ecological Status in Natura 2000 Protected Areas Than Non-Protected Ones?-The Case of Greece. Water 2021, 13, 3007. https:// doi.org/10.3390/w13213007

Academic Editor: Ana Iglesias

Received: 19 July 2021

Accepted: 22 October 2021

Published: 26 October 2021

Publisher's Note: MDPI stays neutral with regard to jurisdictional claims in published maps and institutional affiliations.

Copyright: (c) 2021 by the authors. Licensee MDPI, Basel, Switzerland. This article is an open access article distributed under the terms and conditions of the Creative Commons Attribution (CC BY) license (https:// creativecommons.org/licenses/by/ $4.0 /)$.
Hellenic Centre for Marine Research, Institute of Marine Biological Resources and Inland Waters, Athens-Sounio Ave., 19013 Anavyssos, Greece; mstoum@hcmr.gr (M.S.); elias@hcmr.gr (E.D.); nskoul@hcmr.gr (N.T.S.)

* Correspondence: kstefanidis@hcmr.gr (K.S.); anthioikonomou@hcmr.gr (A.O.); Tel.: +30-2291076439 (K.S.)

+ Konstantinos Stefanidis and Anthi Oikonomou should be considered joint first author.

\begin{abstract}
Regardless of the efforts of the European Union, freshwaters are in a state of environmental crisis. The Water Framework Directive has established a basis for the protection and restoration of European inland and coastal waters. In parallel, the Birds and Habitats Directives protect, maintain or restore, at favourable conservation status, selected species and habitats under a representative network of protected areas. Hence, the interplay between the EU regulations is of high scientific interest and practical relevance. In this article, Greece is used as a case study to explore whether anticipated synergies between the Water Framework Directive and the Nature Directives result in a better ecological status in the protected areas than in the non-protected ones. We investigated whether the ecological qualities that are defined by three biological quality elements (BQEs) differ between the WFD monitoring sites that are located within the Natura 2000 protected areas and those that are not. We identified a total of 148 river monitoring sites that are located within the Natura 2000 network, which corresponds to $30 \%$ of the WFD monitoring network. By employing ordered logit models for each $\mathrm{BQE}$, we found that the ecological quality has the same likelihood to fail the WFD target of "good" quality for sites that are located within and outside the Natura 2000 protected areas. Our results confirmed our hypothesis that the EU directives have little synergy when it comes to restoration of ecological status of Greek running waters, according to the WFD.
\end{abstract}

Keywords: Water Framework Directive; Habitats Directive; ecological status; ecosystem management; ecological monitoring; rivers

\section{Introduction}

Surface freshwater ecosystems contain only $0.01 \%$ of the world's water and cover only about $0.8 \%$ of the Earth's surface [1]. At the same time, they host at least 126,000 species of freshwater animals and vascular plants; this is estimated to be as much as $12 \%$ of all known species, including one-third of all vertebrate species [2]. These ecosystems are also key to flood and erosion control and provide a range of different goods and services (i.e., supplying clean water, producing food and providing energy) that underpin our economies. However, freshwaters are in a state of global crisis; in Europe, as in the rest of the world, the prognosis for freshwater biodiversity is worsening, with freshwater habitats exhibiting steeper deterioration rates than the terrestrial ones [3]. They suffer from anthropogenic pressures, meaning human activities that affect the environment, including land-use change, water extraction, pollution, flow modification, climate change and invasive species $[2,4]$.

The EU is taking action on multiple fronts to safeguard the status of aquatic ecosystems. These international goals and commitments are also reflected within the EU through a range of policies, regulations and directives. The European network of Natura 2000 protected 
areas stretches across all $27 \mathrm{EU}$ countries. The aim of the network is to ensure the longterm survival of Europe's most valuable and threatened species and habitats, listed under the Habitats Directive 92/43/EEC (HD) and the Birds Directive 2009/147/EC (BD). The Habitats Directive adopted in 1992 constitutes the backbone of the EU's biodiversity policy and aims to protect, maintain or restore, at a favourable conservation status, selected species and habitats under a representative network of sites (Sites of Community Importance, SCIs). Once the SCIs have been adopted, member states must designate them within six years as Special Areas of Conservation (SACs), by prioritizing the most threatened and/or most important sites for conservation and by taking the necessary management or restoration measures that ensure the favourable conservation status. The Birds Directive is the oldest cornerstone of EU legislation on the environment, being adopted in 1979 [5] and later amended in 2009 [6]. It focuses on the conservation of birds (threatened and migratory species in particular) and the most important territories for these species, which form the network of Special Protection Areas (SPAs). SPAs and SCIs/SACs together comprise the Natura 2000 network.

The integration of biodiversity conservation into water policies in practice, however, was not seen until the adoption of the Water Framework Directive (WFD; 2000/60/EC), which aims, among others, to restore or maintain good ecological state of freshwater systems. The WFD provides very detailed guidelines for the implementation of ecological monitoring and assessment of European inland and coastal waters, including rivers and streams. Most important, the WFD provides the framework for the implementation of management and restoration measures at a catchment scale, in order to protect the aquatic ecosystems by improving water quality and preventing their deterioration. This means that management and restoration actions are taken under the prism of an ecosystembased approach, which targets the "ecological status" that expresses the quality of the structures and functions of the aquatic ecosystems (WFD, Annex V, Article 2 (21)). The general goal of the WFD for all surface freshwaters is ecological protection and a general minimum chemical standard. The "good ecological status" is defined in Annex V, in terms of quality of the biological community, using a multiple-taxa approach, based mainly on diatoms, benthic invertebrates and fish. The ecological status is estimated by comparing the biological community in each site under question to the respective community that would be expected in environmental conditions of minimal anthropogenic impact (usually historical reference sites). Good chemical status of water is defined in terms of compliance with all the quality standards established for chemical substances at the European level, ensuring a minimum chemical quality compared to the near-natural reference state of the respective aquatic system without human impacts. Moreover, the WFD aims at implementing all necessary measures to progressively reduce pollution from the most hazardous chemical substances' discharges in all surface water bodies. The WFD is in many ways integrated into a spider web of relationships with other directives and documents of European policy [7], since surface water bodies are often found (entirely or partially) in a Special Protection Area (SPA) under the Birds Directive and/or in a Site of Community Importance (SCI) under the Habitats Directive. Practically, the implementation of the WFD and the fulfilment of the objectives depends on the measures proposed by the River Basin Management Plans (RBMPs) and the Programmes of Measures (PoMs) of river reconstruction, rehabilitation or restoration. In Greece, the implementation of the WFD started with some delay [8], and the second round of the RBMPs was approved in 2017, with two years delay [8]. Since 2018, the second phase of the national monitoring programme is running and expected to end in 2023.

Despite the importance of freshwater biodiversity, protected area networks have been historically established for terrestrial conservation [9]. In the EU, a large proportion of threatened biodiversity is not adequately covered by the Natura 2000 areas [10,11]. This is especially true for freshwater or freshwater-related taxa, where only $14 \%$ of European freshwater fish and $19 \%$ of dragonflies listed as threatened in the IUCN Red List are designated under the HD ([9] and references therein). In 2010, the Convention on Biological Diver- 
sity [12,13] adopted the Strategic Plan for Biodiversity, 2011-2020. However, there has been little or no progress towards its targets, and biodiversity continues to decline, especially in freshwaters [14]. Post-2020 actions include the development of the post-2020 global biodiversity framework towards the 2050 Vision of "Living in harmony with nature" [15]. There is an interlinked, parallel process in Europe for the EU's contribution to the upcoming international negotiations on the global post-2020 biodiversity [16]. This strategy reflects the commitment undertaken by the EU Biodiversity Strategy in 2020 [17] to halt freshwater biodiversity loss and improve the state of Europe's species, habitats, ecosystems and the services they provide, since "greater efforts are needed to restore freshwater ecosystems in order to achieve the objectives of the Water Framework Directive" [16]. Moreover, evidence shows that the targets defined under the Convention on Biological Diversity (CBD) are insufficient to adequately protect and restore nature. To this aim, member states should legally protect a minimum of $30 \%$ of the EU's land area and demonstrate significant progress in legally designating new protected areas, concomitantly integrating ecological corridors. On this basis, the European Commission (EC) will assess by 2024 whether the $\mathrm{EU}$ is on track in meeting its 2030 targets or whether stronger actions, including further EU legislation, are needed. The WFD could also provide a significant contribution towards achieving these targets, since member states and the Commission could integrate key water policies, both within and beyond the Natura 2000 areas. Improvement of water status and protection of Natura 2000 sites are found to be mutually reinforcing goals with an integrated approach of both Natura directives and the WFD ensuring healthy aquatic ecosystems, and at the same time a balance between water/nature protection and the sustainable use of natural resources (Article 4. 1c, Article 11 (3)). In other words, the measures taken in river management plans would improve the conservation status of water-dependent habitats and species, through improved water quality and management [18]. One of the fewest examples of good coordination between nature conservation and water management is the "Landshuter Modell", which was developed in Southern Germany and is a successful model of integrating the N2000 objectives and measures into RBMP for the development of the ecological functions of surface waters [19]. Measures and actions include the selection of habitats and species within the selected sites being related to WFD-relevant water bodies, the "translation" of N2000 objectives for habitats and species described in existing management plans into WFD's hydromorphological objectives and measures and the integration of selected objectives and measures into RBMPs. Moreover, the ecosystem approach adopted in Austria's National Water Framework Plan and the priority given to hydromorphological issues through the restoration of dynamic floodplains and their drift zones will not lead only to the improvement of the ecological status of the rivers under the WFD but should also enhance the conservation condition of the Natura 2000 sites, species and habitats present.

In water-dependent Natura 2000 sites that are monitored under the WFD, measures that target a good ecological status might contribute to the achievement or maintenance of the favourable conservation status of aquatic habitats or species of conservation concern, including indirect effects on birds (in SPAs, BD), HD Annex II species and HD Annex I habitats $[7,18]$. However, the Birds and Habitats Directives and the WFD are currently implemented separately, thereby potentially hampering the achievement of their respective goals. As a result, there is an increasing awareness in the EC and the European Environment Agency (EEA) about the need of improving coherence among the different directives (e.g., [20]). Despite the overlaps across those policies, there is no previous study assessing ecological status patterns in an EU member state's NATURA 2000 network.

In this study, using Greek water-dependent Natura 2000 areas as a test case, we investigated whether the ecological status derived from the WFD monitoring programmes is higher in the Natura 2000 areas than in sites outside the Natura 2000 network. Our hypothesis was that the ecological quality deriving from the assessment of three biological quality elements (fish, benthic invertebrates and benthic diatoms) would be higher at riverine sites found within the Natura 2000-protected areas than at sites outside the pro- 
tected areas, due to the combined effect of management actions that take place inside the Natura 2000 areas following the HD and those undertaken to achieve good ecological status following the WFD. In addition, we examined whether key environmental stressors (e.g., total phosphorus, total nitrogen and hydromorphological modification) differ between the river sites inside and outside the Natura 2000. In ecology, the term "stressor" may have various definitions, but recently has been commonly used to describe the effect of an anthropogenic activity that exceeds the normal variation and influences the communities and the ecosystem [21]. We hypothesized that water bodies that are included in protected areas should have lower levels of stressors than water courses that are outside the Natura 2000 network.

\section{Materials and Methods}

\subsection{Study Area}

Greece is situated in south-eastern Europe at a crossroads between Europe, Asia and Africa. It is one of the most biodiverse countries in Europe, with high species diversity, extensive coverage of natural areas, lengthy coastline and thousands of islands. This topographic diversity contributes to the high species diversity of flora and fauna, including high endemism [22]. Freshwater ecosystems of Greece are considered as biodiversity hotspots at a regional and global scale [23,24]. The 2009 Greek national red list covered 300 threatened plant species, 422 vertebrates and 591 invertebrates. Of the 422 vertebrate species, $40 \%$ are considered threatened, with one-third of them being freshwater fish $(37.4 \%)$ and about one-fourth amphibians $(27.3 \%)$. In addition, more than half of the 591 invertebrates are threatened with extinction. The Greek Natura 2000 network covers $27.3 \%$ of terrestrial areas [10], while marine protected areas account for $20 \%$ of the territorial sea. Greece thus has achieved the 2020 Aichi target 11 on terrestrial areas, which calls for reaching at least $17 \%$ of terrestrial land and inland waters. In 2017, Greece expanded its Natura 2000 network, with a focus on marine areas, adding 32 new areas and extending the boundaries of 63 existing ones. Half of habitats and species listed in the annexes (habitats in Annex I and species in Annexes II, IV and V) show unfavourable conservation status, due to landscape modification and habitat fragmentation [25]. Moreover, many of the species' habitats and ecological corridors are distributed outside protected areas.

\subsection{Compilation of Data}

The WFD monitoring network includes 490 sites distributed in rivers and streams from 14 river basin districts, which cover the entire national terrestrial territory. The ecological quality monitoring of the running waters of Greece is implemented by the Institute of Marine Biological Resources and Inland Waters (IMBRIW) of Hellenic Centre for Marine Research (HCMR). The ecological and water quality monitoring started in 2012, albeit later than most of the EU countries, but since then it is systematically implemented for all four biological quality elements (BQEs) and the supporting physiochemical and hydromorphological quality elements. Reference conditions have been defined for each intercalibration type (ICT) of rivers, according to the available information for the biological quality elements (BQEs), the physicochemical and hydromorphological conditions. Intercalibration types (ICTs) are used by each geographic intercalibration group in order to identify water bodies with common characteristics. This river typology facilitates the ecological assessment with the use of BQEs. Six intercalibration river types in the Mediterranean are described as R-M1: Small, medium altitude Mediterranean streams with strong seasonal flow; R-M2: Small-medium lowland Mediterranean streams; R-M3: Large Mediterranean streams with strong seasonal flow; R-M4: Small-medium Mediterranean mountain streams with strong seasonal flow; R-M5: Small lowland temporary streams with temporary flow; VL: Very large rivers. In this study, we identified a total of 148 sites of the WFD monitoring network that are located within the boundaries of 109 Natura 2000 protected areas (Figure 1, Table 1). 


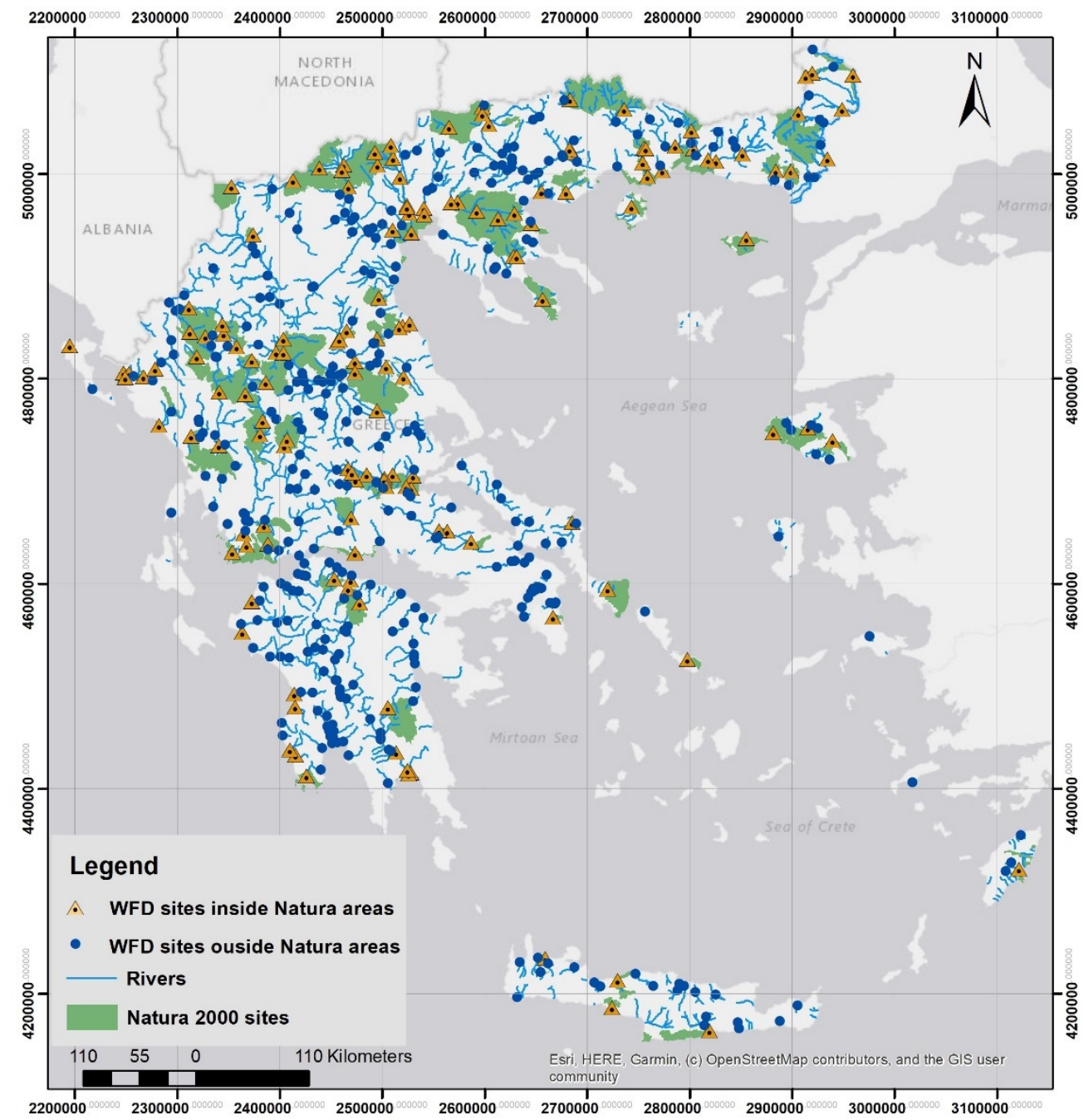

Figure 1. Distribution of WFD monitoring sites that are located within and outside Natura 2000 protected areas.

Table 1. Distribution of monitoring sites that are contained in Natura protected areas per water district.

\begin{tabular}{ccc}
\hline River Basin District (RBD) & $\begin{array}{c}\text { No. of Sites within } \\
\text { Protected Area }\end{array}$ & Total Number of WFD Sites \\
\hline GR01 (Western Peloponnese) & 5 & 44 \\
GR02 (Northern Peloponnese) & 6 & 34 \\
GR03 (Eastern Peloponnese) & 5 & 18 \\
GR04 (Western Sterea Ellada) & 14 & 45 \\
GR05 (Epirus) & 17 & 40 \\
GR06 (Attica) & 1 & 13 \\
GR07 (East. Sterea Ellada) & 17 & 44 \\
GR08 (Thessaly) & 15 & 54 \\
GR09 (Western Macedonia) & 9 & 38 \\
GR10 (Central Macedonia) & 20 & 36 \\
GR11 (Eastern Macedonia) & 8 & 35 \\
GR12 (Thrace) & 23 & 46 \\
GR13 (Crete) & 4 & 25 \\
GR14 (Aegean Islands) & 5 & 18 \\
Total & 148 & 490 \\
\hline
\end{tabular}

We obtained land-use data for each basin that included an aforementioned sampling site from the database of the IMBRIW. Land uses were aggregated at the first level of 
CORINE classification, and three main classes were defined: artificial, agriculture and near natural. Measurements of total nitrogen (TN) and total phosphorus (TP) concentrations were obtained from the results of the national monitoring programme in Greek rivers for the period 2018-2020. For the description of the hydromorphological modifications, we used the Habitat Modification Score (HMS), calculated from surveys during the same period [26,27].

Monitoring data on the ecological quality of the running waters of Greece, based on three BQEs (benthic invertebrates, benthic diatoms and fish), were obtained also from the database of the IMBRIW. We compiled 89, 165 and 149 cases of ecological quality based on fish, benthic invertebrates and benthic diatoms, for four time periods (i.e. spring 2018, summer 2018, spring 2019 and summer 2019) for 45, 54 and 53 sites, respectively, that are distributed inside the Natura 2000 protected areas. To compare those qualities with sites outside the Natura network, we randomly selected an equal number of cases for each BQE using the sample function in $\mathrm{R}$ environment. Thus, we generated three datasets, one for each BQE, with 178, 330 and 298 cases, respectively, equally distributed inside Natura 2000 vs. outside Natura 2000 areas, for the same seasons and years of sampling (spring 2018, summer 2018, spring 2019 and summer 2019).

\subsection{Statistical Analysis}

First, we explored for significant differences between the medians of main land uses (artificial, agriculture and near natural) for the basins of WFD sites located within and outside the designated Natura areas with a Kruskal-Wallis non-parametric test. We also tested for significant differences between the medians of altitude and slope as well as HMS, TN and TP within and outside the Natura 2000 protected areas. Boxplots were created to visually assess the differences.

Concerning the ecological qualities, we also tested for significant differences for the distributions of the ecological quality classes within and outside the Natura 2000 areas with a Kruskal-Wallis non-parametric test. Then we employed ordered logistic regression to model the probability of the ecological quality to meet a specific class (i.e., bad, poor, moderate, good or high). The ordered logistic regression or ordered logit model is a regression model used for analysing ordinal responses [28]. It is defined by a set of equations where the cumulative probabilities are related to linear predictors through a logit function. Here, we used the ecological quality class for each BQE, as an ordinal response, ranging from "bad" to "high" (5 categories). Thus, we created three models, one for each BQE with the conservation status (2 levels), the season and year of the field sampling (2 levels each) and the intercalibration type of the water body in which the site is located (6 levels) being used as predictors. Models were developed in R environment using the polr function of the MASS package [29].

\section{Results}

\subsection{Water Quality and Hydromorphological Modifications}

We tested for significant differences in the Habitat Modification Score (HMS), total nitrogen (TN) and total phosphorus (TP). The results of Kruskal-Wallis test revealed a small significant difference for TN $(p=0.012)$, with sites outside the Natura protected areas showing higher TN levels (median $1.23 \mathrm{mg} / \mathrm{L}$ ) than the sites that belong to the Natura network (median $1.04 \mathrm{mg} / \mathrm{L}$ ) (Table 2). On the contrary, the median of TP was higher for sites within Natura areas $(0.049 \mathrm{mg} / \mathrm{L})$ than those outside Natura network $(0.04 \mathrm{mg} / \mathrm{L})$, but the difference was not statistically significant. We also compared the shares of main land uses within the basins between monitoring sites that are located within the Natura 2000 network and those that fall outside the Natura boundaries. A significant difference concerns the percentage share of the near-natural land use being considerably higher within the Natura protected areas $(p=0.034)$, whereas the percentage share of the artificial land cover is lower within the Natura areas, but marginally not significant (Table 2). The remainder parameters did not show statistically significant differences, which means that 
the degree of hydromorphological modification, the concentration of TP and the presence of agriculture and artificial surfaces, the altitude and the slope show the same distribution in each basin, regardless of being inside or outside the Natura network (Figures 2 and 3).

Table 2. Results of the Kruskal-Wallis rank sum test for land uses, altitude, slope, HMS, TN and TP. Values in bold are significant $(p \leq 0.05)$.

\begin{tabular}{ccc}
\hline & Chi-Squared & $p$-Value \\
\hline \% Agriculture & 2.385 & 0.123 \\
\% Artificial & 3.614 & 0.057 \\
$\%$ Near Natural & 4.551 & $\mathbf{0 . 0 3 4}$ \\
Altitude & 3.6232 & 0.057 \\
Slope \% & 2.2602 & 0.133 \\
HMS & 0.255 & 0.631 \\
TN & 6.207 & $\mathbf{0 . 0 1 2}$ \\
TP & 3.087 & 0.078 \\
\hline
\end{tabular}
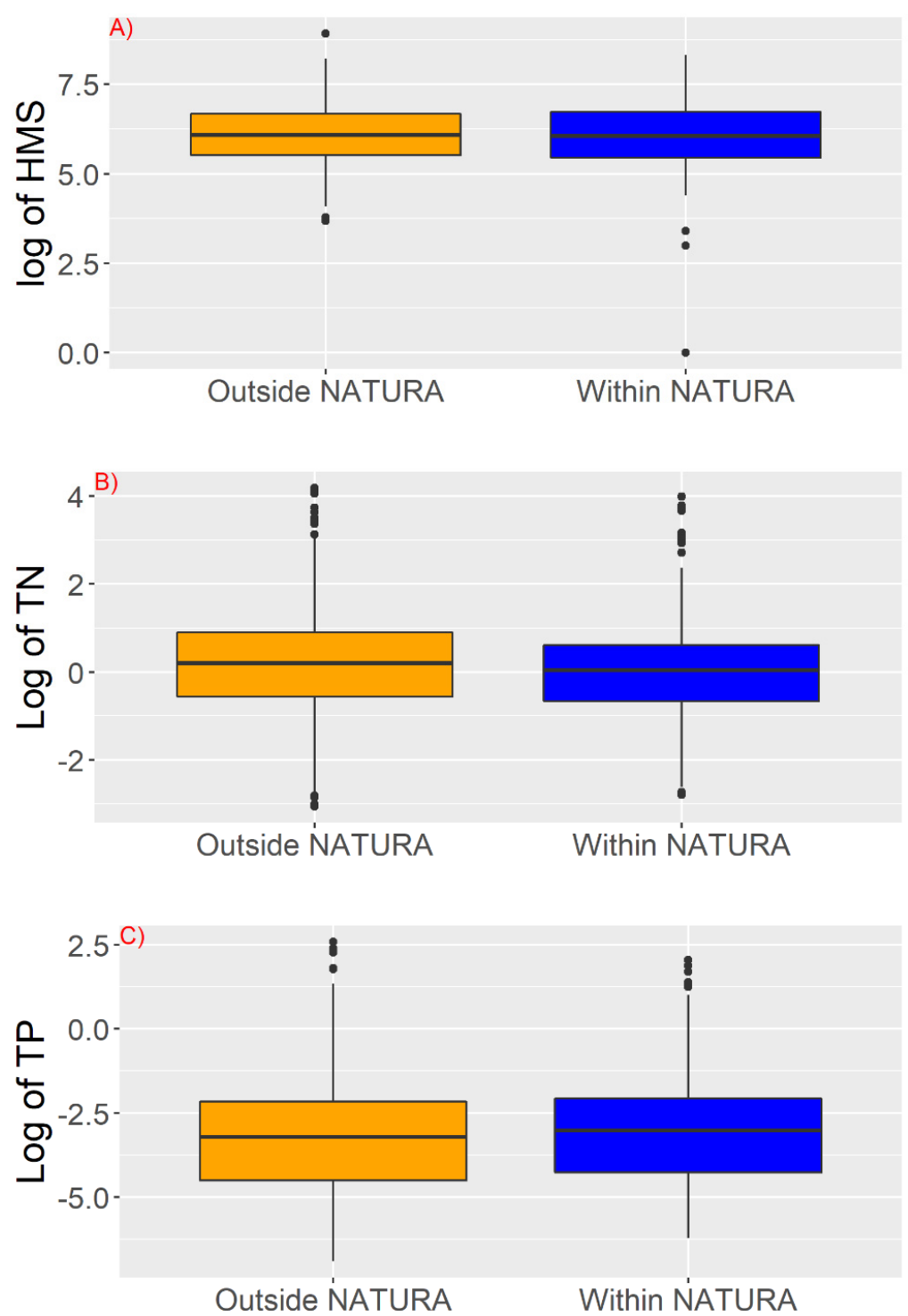

Figure 2. Boxplots of (A) Habitat Modification Score (HMS), (B) total nitrogen and (C) total phosphorus between WFD sites outside and within Natura protected areas. 

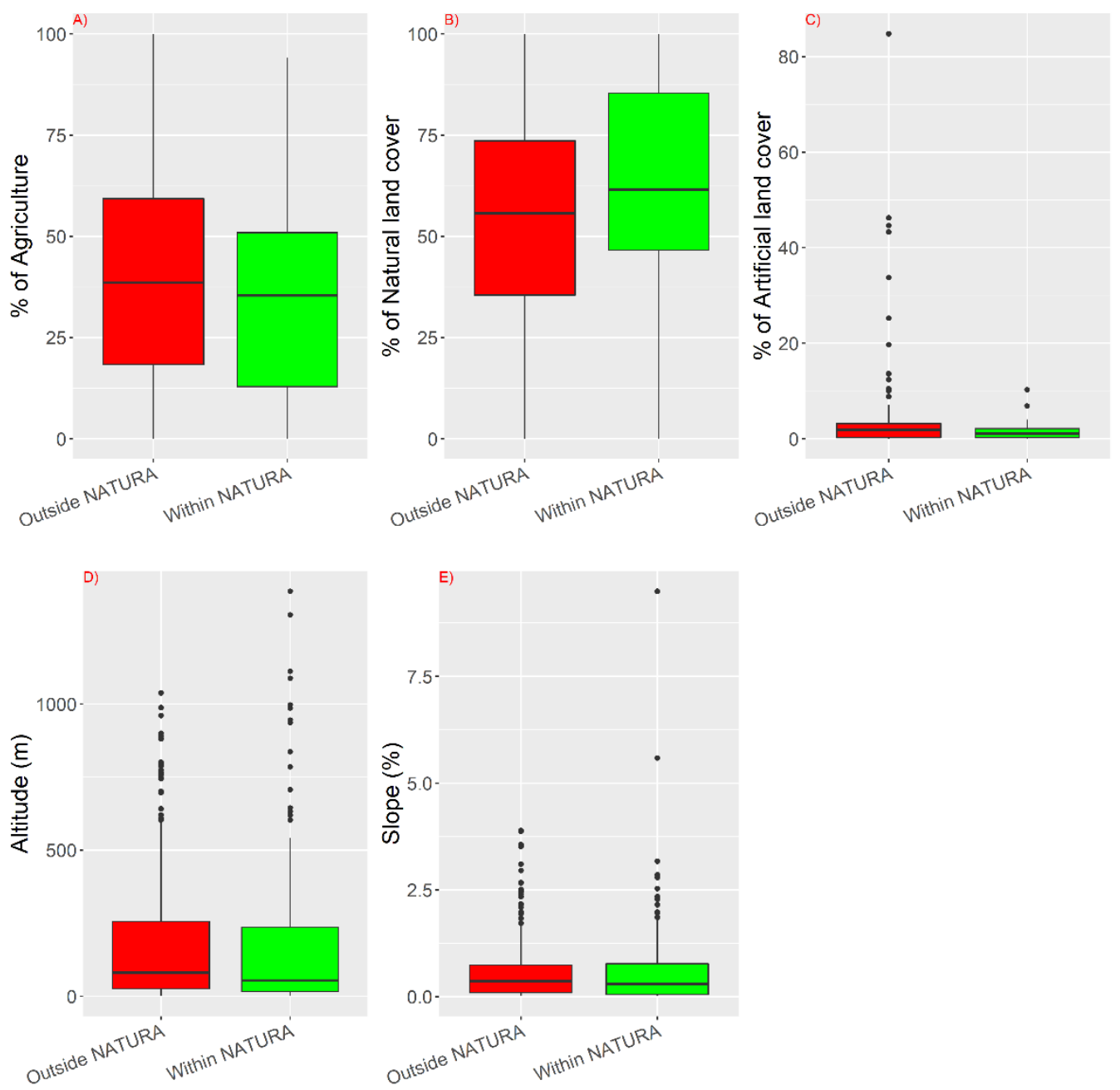

Figure 3. Boxplots of percentage shares of (A) agriculture, (B) natural land cover and (C) artificial land cover, (D) altitude and (E) slope within basins of WFD sites outside and within Natura protected areas.

\subsection{Ecological Quality within and outside the Natura Network}

The distribution of ecological quality classes based on fish and macroinvertebrates did not present significant differences between the sites within and outside the Natura 2000 network (Table 3). Regarding the assessments based on fish, there are more sites classified with poor and high and less with bad and good ecological quality within the Natura 2000 areas (Figure 4). Overall, the share of the sites below the good ecological quality remains the same on both occasions. For benthic macroinvertebrates, there are more sites with good quality within the Natura network, but this difference is offset by a decrease in the share of sites with high quality (Figure 4). Conversely, for benthic diatoms, we noted a small significant difference $(p=0.018)$ where the share of sites within Natura with good ecological quality is lower than that of the sites outside Natura areas (Figure 4).

Table 3. Results of the Kruskal-Wallis rank sum test for sites within and outside Natura network. Values in bold are significant $(p \leq 0.05)$.

\begin{tabular}{cccc}
\hline & Fish & Macroinvertebrates & Diatoms \\
\hline Chi-squared & 0.334 & 3.499 & 5.576 \\
$p$-value & 0.563 & 0.061 & $\mathbf{0 . 0 1 8}$ \\
\hline
\end{tabular}



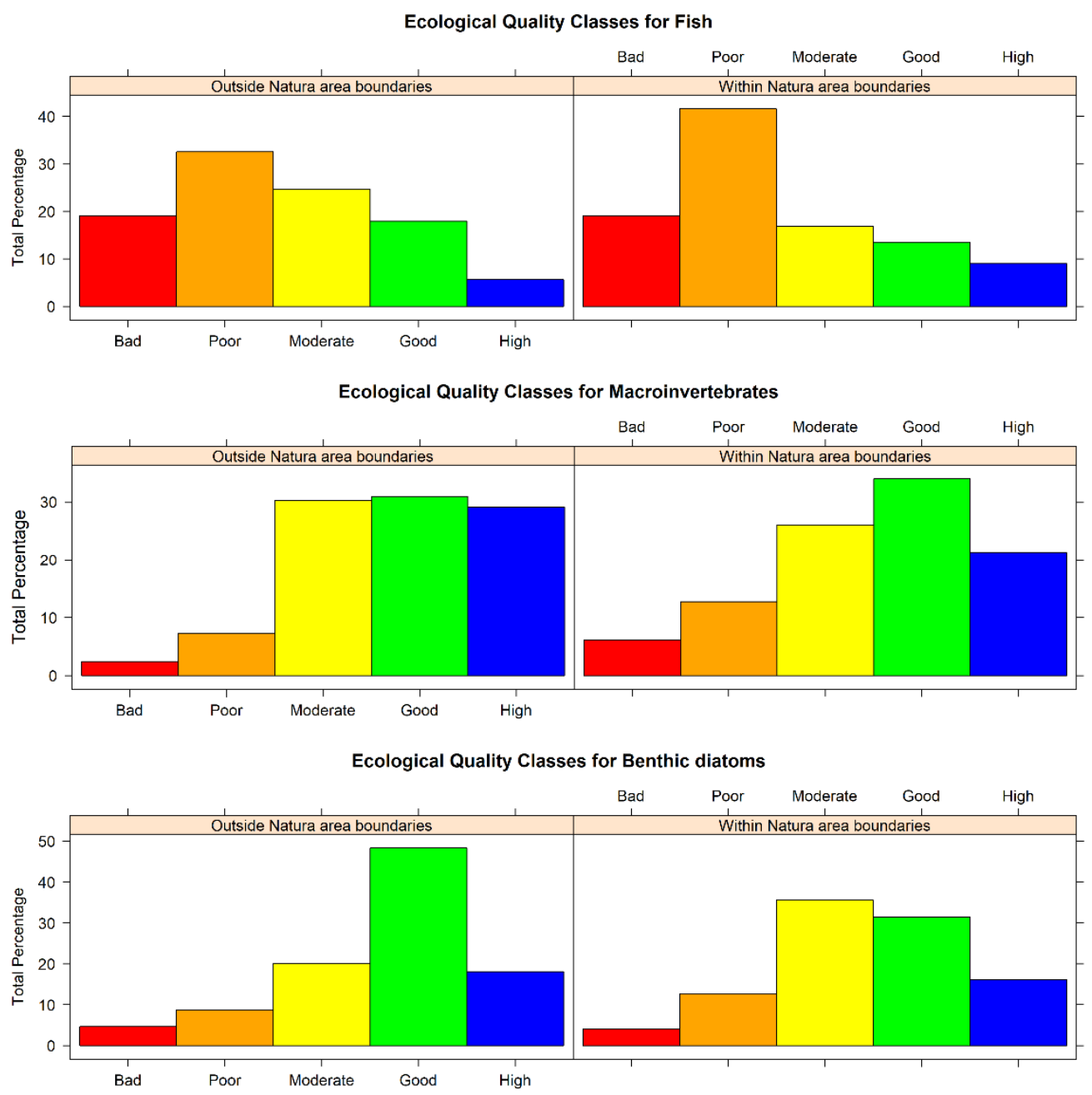

Figure 4. Distribution of classes of ecological quality for each BQE outside and within SCI/ SPA boundaries.

The results of the ordered logistic regression further confirmed the aforementioned observations, as the protection status of the sites (Natura protected areas vs. areas outside the Natura network) was not a significant predictor of ecological quality class for any BQE (Table 4). Thus, the probability for a certain ecological quality class is not affected by the protection status within a Natura 2000 area (Figure 5). On the other hand, considering the whole data set, the typology is a significant predictor for all BQEs, as there are notable differences in the estimated probabilities of ecological quality classes among the various river types (Figure 6). For instance, we can see a remarkable low probability (less than $20 \%$ ) for sites belonging to very large rivers to achieve the WFD target of good quality based on benthic invertebrates. For fish, the probability for sites belonging to R-M5 and very large rivers to achieve the WFD target is even less.

Another interesting finding is that the estimated probabilities of the quality classes are similar for benthic invertebrates and diatoms, with a probability of 0.6 approximately to achieve the good ecological quality, regardless the protection status. Conversely, for fish, the probability for a site meeting the target of good ecological quality is much less, estimated about 0.2 . For certain types of rivers (R-M5 and Very Large rivers), the probability is much lower (around 0.1). 
Table 4. Results of proportional odds logistic regressions for each biological quality element (BQE). NS: Non-significant.

\begin{tabular}{ccccc}
\hline Response & Conservation & Predictors & River Type \\
Status & $\begin{array}{c}\text { Sampling } \\
\text { Season }\end{array}$ & Year \\
\hline $\begin{array}{c}\text { Ecological quality class based on fish } \\
\begin{array}{c}\text { Ecological quality class based } \\
\text { on macroinvertebrates }\end{array}\end{array}$ & $\mathrm{NS}$ & $p=0.021$ & $\mathrm{NS}$ & $\mathrm{NS}$ \\
$\begin{array}{c}\text { Ecological quality class based on } \\
\text { benthic diatoms }\end{array}$ & $\mathrm{NS}$ & $p \leq 0.001$ & $\mathrm{NS}$ & $\mathrm{NS}$ \\
\hline
\end{tabular}

\section{Ecological Quality Classes based on Fish}

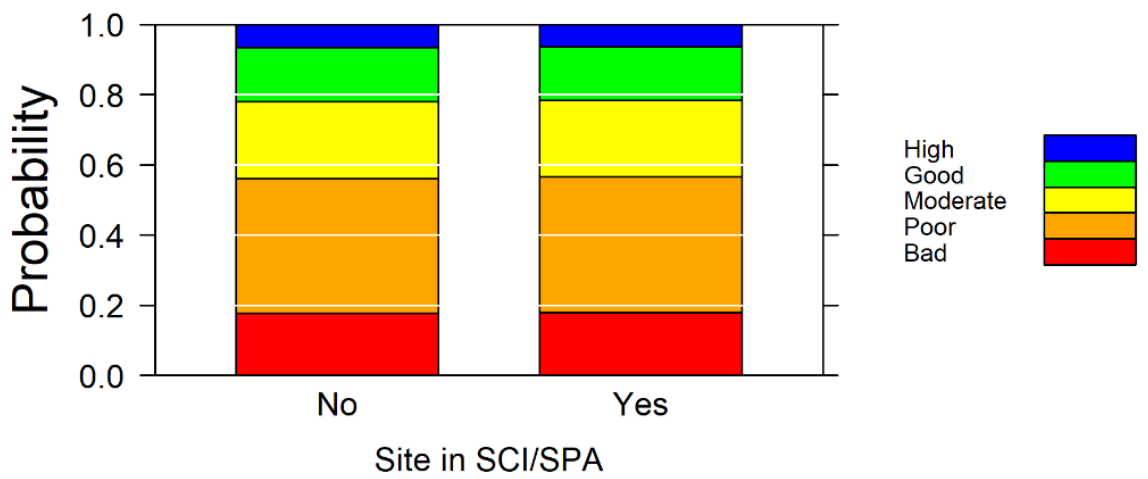

\section{Ecological Quality Classes based on Macroinvertebrates}

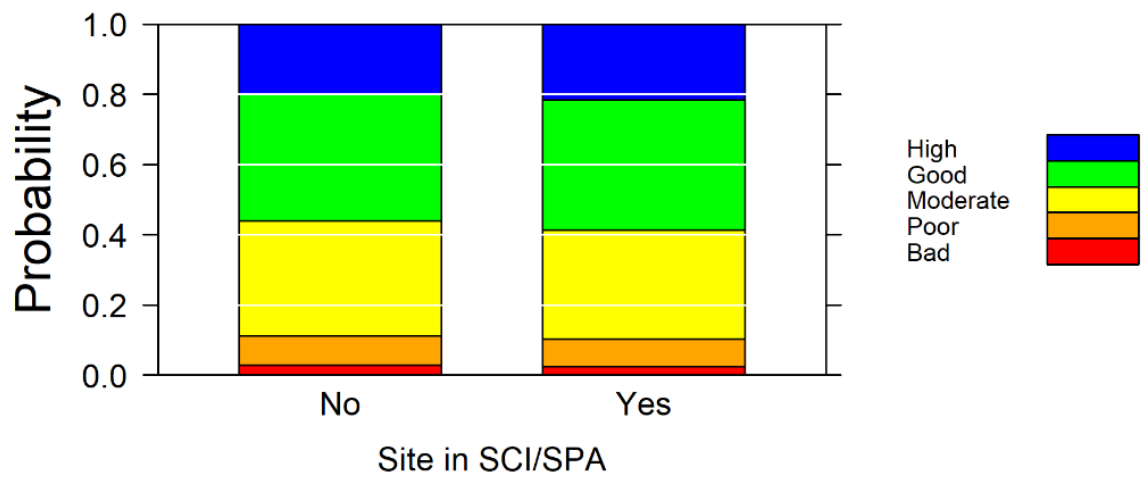

\section{Ecological Quality Classes based on Benthic diatoms}

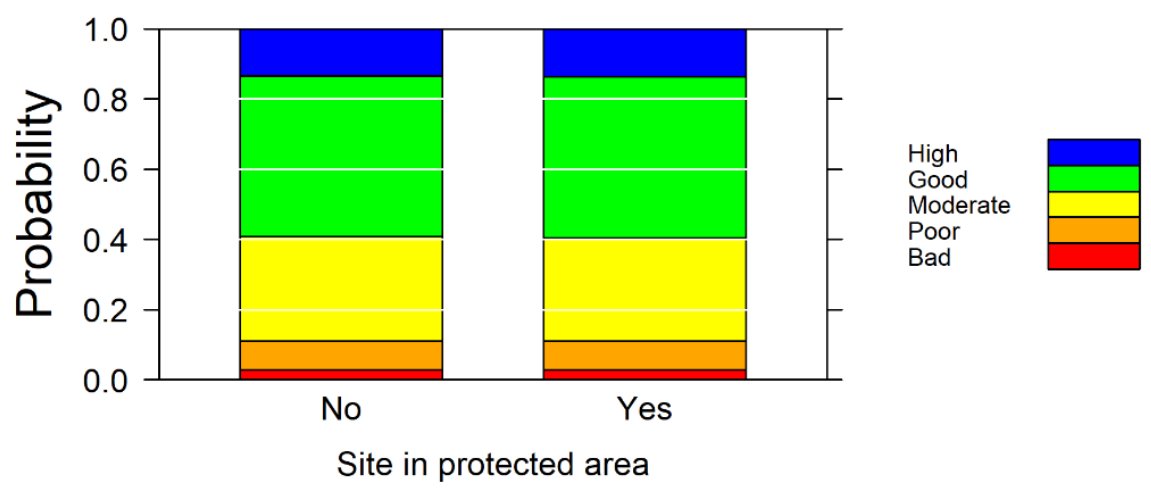

Figure 5. Predicted probabilities of ecological quality classes derived by proportional odds logistic regressions for each $\mathrm{BQE}$ per ICT. 


\section{Ecological Quality Classes based on Fish}

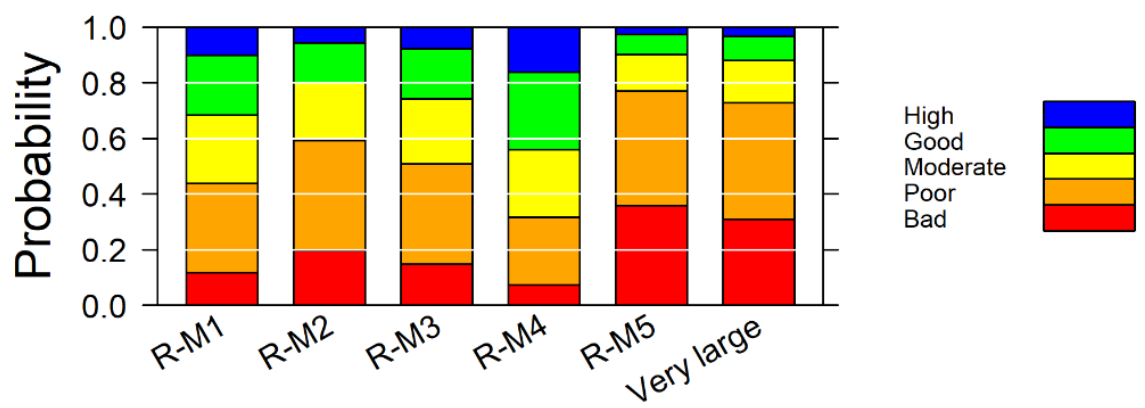

ICTs

\section{Ecological Quality Classes based on Macroinvertebrates}

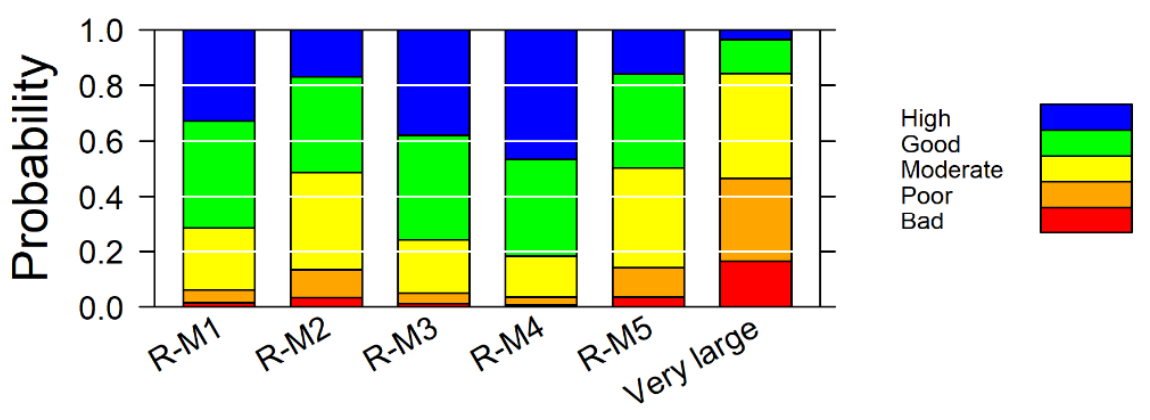

ICTs

\section{Ecological Quality Classes based on Benthic diatoms}

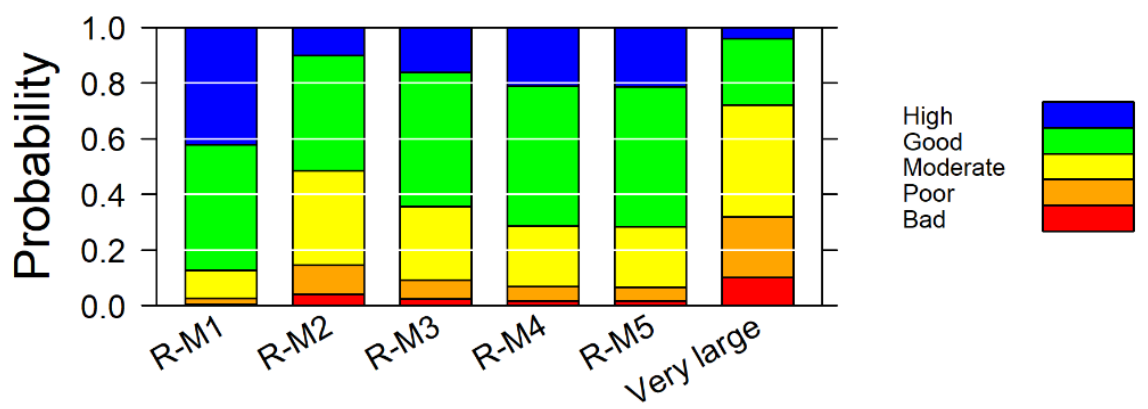

ICTs

Figure 6. Predicted probabilities of ecological quality classes derived by proportional odds logistic regressions for each $\mathrm{BQE}$ per ICT.

Finally, the ecological quality based on diatoms is influenced by the seasonality (Table 4). The probability of good and high ecological quality decreases from spring to summer in both years (2018 and 2019), whereas the probability of moderate, poor and bad quality increases (Figure 7). For fish and benthic invertebrates, there are slight differences between the sampling seasons. 
Ecological Quality Classes based on fish

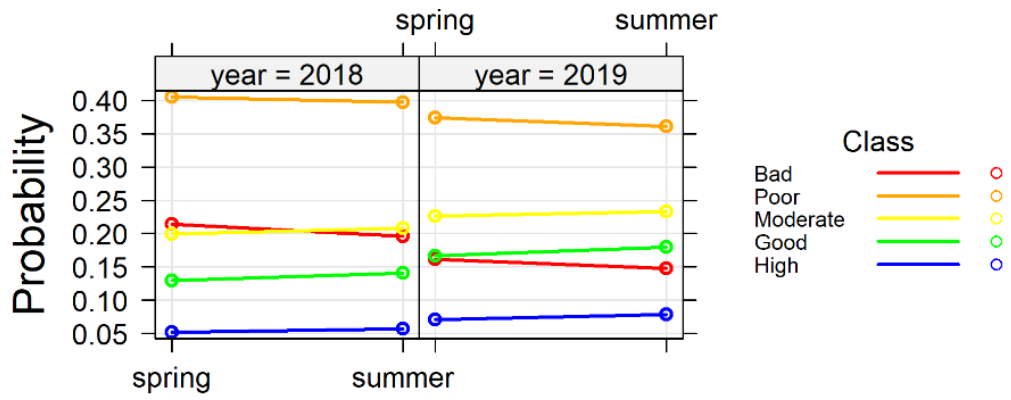

\section{Ecological Quality Classes based on macroinvertebrates}

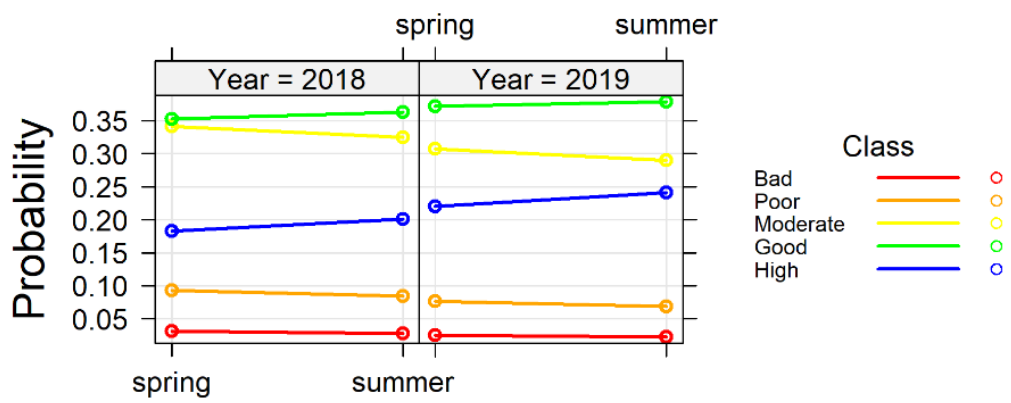

Ecological Quality Classes based on diatoms

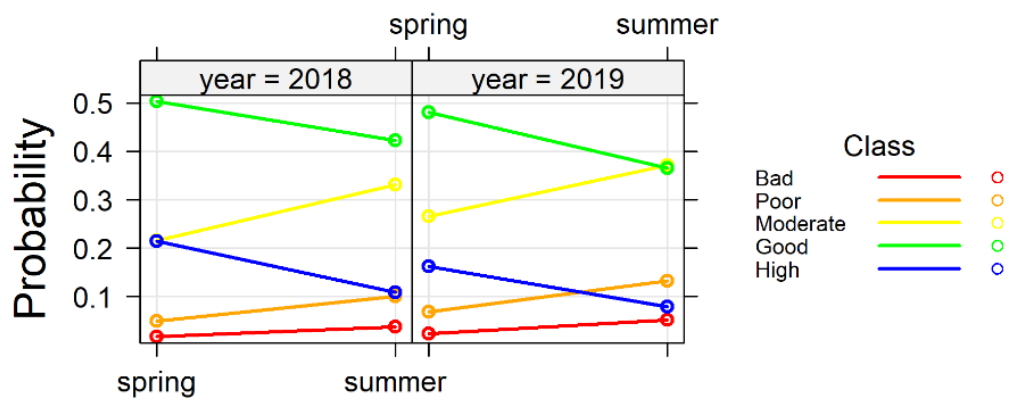

Figure 7. Predicted probabilities of ecological quality classes for each BQE per sampling season and year.

\section{Discussion}

With this study, we showed that a large share of the Greek national monitoring network of rivers for the implementation of the WFD is contained within the Natura 2000 protected areas $(30 \%)$. Since there is an obvious overlap between the goals of the WFD and Natura 2000 directives, one should expect a synergy of measures that target the recovery of water bodies located within Natura 2000 areas. However, we showed that this is not the case as the ecological quality, regardless of BQE, did not differ between WFD sites within and outside Natura 2000 areas. We also showed that there are small differences with respect to main stressors (hydromorphological modifications and TP) acting at riverine reaches located within or outside Natura areas. This finding is important, and it appears as an ecosystem management paradox, meaning that despite the implementation of different EU policies, environmental targets have failed. It raises the question why water bodies within Natura 2000 protected areas fail to meet the WFD target and pinpoints the need to further examine the effectiveness of restoration measures and current management practices.

Generally, the coordination between different policies is considered a major issue for environmental management and protection [30]. As environmental policies are accumulating and becoming more complex, the challenge of integration increases $[30,31]$. 
Particularly for the water, the need for the integration of policies has been acknowledged and linked with the different water uses [32] (e.g., agricultural, drinking, bathing and others). Nevertheless, problems with the integration and coordination between policies might be attributed to different reasons such as institutional overlap and friction [32]. As the governance regime increases, the interlinkages between institutions such as public policies, public law and private properties create obstacles, described as transversal transaction costs (TTCs), which limit the efficiency of the regime. This theoretical framework is described as Institutional Complexity Trap (ICT) [33], which simply describes the situation where the negative impact from the increasing TTCs offset the positive impact of the increasing extent of the governance regime.

The ICT framework could explain at a certain degree the failure of achieving environmental goals of directives that seemingly overlap, particularly if we consider the complex interplay of the WFD with other policies [7]. Another explanation is that the actions implemented according to River Basin Management Plans have failed to tackle the adverse effects of pressures on both the Natura-related water bodies and the non-related ones. In fact, reports from Europe's first River Basin Management Plans (RBMPs) have revealed that almost $56 \%$ of European rivers have failed to achieve the good status target of the Water Framework Directive (WFD) [34]. In Greece, the respective percentage was $32 \%$ [8]. The reason that RBMPs have failed to improve the ecological status is a more complex matter. Recent evidence from the literature [35-37] shows that synergistic and antagonistic interactions between multiple stressors pose challenges for the managers. Common stressors for the aquatic environment are the nutrients as a result of anthropogenic pollution (e.g., phosphorus and nitrogen), and hydrologic alteration due to water abstraction. Multiple stressors occur when two or more stressors operate simultaneously, which is often the case for many European systems [36]. When multiple stressors do not interact, river managers may choose to tackle the dominant stressor, to achieve the best management effect. In an interactive setting, it is likely that the interaction effect of two or more stressors in concert is stronger than their additive effect [38,39]. In this case, managers will have to adapt the selection of measures to address the combined effect. Several examples of synergistic effects on aquatic biota have been experimentally investigated. For instance, Calapez et al. [40] showed that the combined effect of water flow reduction and hypoxia on macroinvertebrates is higher than the effect of each stressor separately. It is evident that the causes of degradation of European surface waters can be complex, and the Programmes of Measures (PoMs) included in the RBMPs may not have the potential to address multiple stressor situations. Physical alterations affecting river hydromorphology as well as diffuse-source pollution are shown to be the key challenges in WFD implementation [41]. With nutrients and hydromorphological alterations being common stressors in many rivers of Greece $[42,43]$ that act in concert, we cannot exclude the possibility of synergistic effects that offset the implemented measures. For example, Smeti et al. [44] showed that co-occurring stressors of flow intermittency and nutrient pollution had a significant effect on biodiversity of invertebrates and diatoms and related ecosystem functions in a Greek intermittent river.

Here we found that TP and hydromorphological modification, two common pressures, did not differ significantly between the Natura-related water bodies and the non-related ones. In practice, water bodies face the same problems regardless of them being part of a Natura protected network. Moreover, Greece has adopted and reported the second generation of River Basin Management Plans under the Water Framework Directive, albeit with a long delay. The EC has therefore not yet conducted an assessment and has not been able to assess the status and development since the first EIR report [45].

Even so, we cannot exclude the possibility of weaknesses of the BQE-related indices to accurately capture the impacts of certain pressures on the aquatic biota. For instance, we have noticed an obvious dissociation between the fish and the other BQEs, which may reflect the differentiated susceptibility of fish to particular pressures in relation to macroinvertebrates and diatoms (i.e., hydromorphological alterations vs. nutrient pollution), but 
also could hint at an issue of status misclassification. The latter could be assessed in future studies by estimating the probability of misclassification with Monte Carlo models that simulate the probability of different ecological assessments [46]. Such an approach could reveal uncertainties in the implementations of biological indices for assessing ecological quality. The higher the uncertainty, the more likely the ecological misclassification.

Yet, we found that the probability of ecological quality class depends on the river type. Thus, there are river types that are more likely to meet the target of "good" ecological status than others. For instance, river types R-M1 and R-M4, which in general are small streams at medium or higher altitudes, showed higher probability of achieving good ecological quality. On the contrary, the type VL, that is, very large rivers, presented a very low probability of falling in a good ecological quality regardless of the assessed BQE. Finally, seasonality was a significant factor only for diatoms, implying that the assessment based on diatoms is more sensitive on seasonal variations of stream conditions (e.g., nutrient availability and flow) [47], resulting in a significant difference between summer and spring sampling period.

Overall, these observations highlight the need, firstly, to properly address pressures that until now have ben insufficiently addressed, both in Natura and non-related Natura areas, and, secondly, to examine the uncertainties related with the application of biological indices. For instance, hydromorphological alteration contributes mostly to explaining the average percentage of deviance in ecological status at the European scale [34]. In the case of Greece, there are not many examples of studies that address this common pressure [48]. Although there is a history in Greece of habitat restoration actions that target hydromorphological degradation in protected areas, these actions concern mostly lakes, coastal lagoons, river deltas and wetlands. In fact, there are insufficient data of hydromorphological monitoring and restoration effects in the Greek streams and rivers [48] as their systematic hydromorphological assessment has only recently begun [26]. Since the effects from measures that restore hydromorphological features have multiple positive effects on the ecosystem and the aquatic organisms [49-51], PoMs for water bodies should work synergistically with biodiversity conservation actions in protected areas and focus primarily on hydromorphological restoration. Such measures may include removal of bed and bank fixation, remeandering, development of a riparian buffer strip, increase of habitat complexity and others that aim to restore a more natural profile of river morphology. Habitat connectivity, sediment transport, nutrient retention and rewetting of floodplains are some examples of river processes that benefit from such interventions and as a result improve ecological functions and services.

As far as the protection of biodiversity in concerned, Greece has made notable progress in biodiversity conservation [25]. Greece is party to all the main biodiversity-related international conventions, including the CBD, the Convention to Combat Desertification, the Convention on International Trade in Endangered Species, the Bern Convention on the Conservation of European Wildlife and Natural Habitats, the Bonn Convention on the Conservation of Migratory Species of Wild Animals, the Ramsar Convention on Wetlands of International Importance and the Framework Convention on Climate Change, the Barcelona Convention for the Protection of the Marine Environment and the Coastal Region of the Mediterranean, but has not yet ratified the protocols on Specially Protected Areas and Biological Diversity and on Integrated Coastal Zone Management. The legal framework was strengthened with laws on biodiversity conservation (2011) and the establishment of the Protected Areas Management Bodies (2018) and the national list of the European Ecological network Natura 2000. Greece has also adopted the National Biodiversity Strategy and Action Plan (NBSAP) for 2014-2029 [52] to improve the status of protection, conservation and management of Greek Protected Areas, after years of political inertia and under the EU pressure for effective protection and full implementation of the environmental directives. However, effective administration and functioning of protected areas is hampered by lack of Special Environmental Studies, drafting presidential decrees and management plans for all areas of the Natura 2000 network, since only six 
management plans have been adopted, covering 2\% of the network's area. Indeed, in 2018, the EC urged Greece to respect its obligations under the Habitats Directive and establish conservation priorities, objectives and measures for all Natura 2000 sites. Although the management plans should improve the management of Natura 2000 sites [45], contributing significantly to the integrated protection of the natural environment in Greece, through the effective institution and management of its protected areas, there was a relative delay in management planning with the estimated preparation and completion date to be in 2021. Additional obstacles in biodiversity conservation are lack of capacity and awareness among authorities and the public [25].

Although the basic objectives of the WFD and the HDs are similar, as they both aim to relieve the stress that is exerted on the biota and their habitats, the integration of the environmental policies Natura 2000 and WFD in Europe is a work in progress. However, there are significant differences when it comes to the implementation of their management goals. We can postulate that measures delivered in Management Plans for the Natura 2000 sites, in accordance with the HDs, which will target certain endangered aquatic species and their habitats, will have very small, if any, effect on the structures and functions of the respective ecosystems. HD targets a few fish species that may also play a lesser role in assessments of ecological quality according to the WFD and disregards species of invertebrates and benthic diatoms (biota that are both BQEs). Exceptions may occur in cases of aquatic plants, since freshwater habitat types are defined by aquatic plant communities. For instance, certain habitat types might be indicative of oligotrophic conditions and good ecological status (e.g., Habitat type 3140 "Hard oligo-mesotrophic waters with benthic vegetation of Chara spp."). Thus, measures for aquatic vegetation that aim at improving the ecological status of Natura 2000 sites should also contribute to the "favourable conservation status" of the aquatic habitat types in the protected areas [53]. Moreover, it is not unusual that two European regulations may have conflicting environmental management goals. Weigelhofer et al. recently reported conflicts between the WFD and the HD, particularly when it concerns the implementation of floodplain restoration projects [54]. Furthermore, Janauer et al. [7] analysed the potential conflicts between these directives and acknowledged the need for establishing common ground with respect to the implementation of management targets; Beunen et al. similarly found that for the Netherlands, the implementation processes of both directives are "largely autonomous and independent" due to the organizational separation of water management and nature conservation [55,56]. Overall, it is surprising that very few economic valuation studies have been carried out that deal with WFD targets and measures in Natura 2000 network [57].

As already stated, the "Landshuter Modell" was developed in Southern Germany and successfully integrates the N2000 objectives and measures into RBMP for the development of the ecological functions of surface waters [7]. Following this model, four other "ecological development concepts" were established at the Isar, the Danube and the Vils rivers between 2003 and 2013. Sundseth [19] describes several case studies on creating synergies between the Water Framework Directive and the Habitats and Birds Directives, demonstrating how various elements of the directives have been coordinated in practice, either at the level of the river basins or across the different authorities responsible for their respective implementation. As an example of an integrated approach between the directives, the National Framework Plan of Austria brings together the two policies, by ensuring "river connectivity" to improve both the river flow dynamics and the overall environmental status of the river, as well as the condition of the riverine habitats and species protected under Natura 2000.

\section{Conclusions}

This study further contributes towards the direction of highlighting the need for better coordination between the EU Directives, particularly when it concerns the implementation of management and restoration schemes. Greek rivers and streams are still under the threat of various anthropogenic pressures, mainly hydromorphological alteration and nutrient 
pollution. Almost five years after Greece has started to systematically monitor the running waters, there is no apparent improvement in their ecological quality. Moreover, what is evident from this study is that the ecological quality of freshwaters within the Natura 2000 protected areas is practically the same with the sites that are not protected by the Habitats Directives. This finding raises concerns for the efficacy of the implemented management measures and also brings forth the question about the compliance between the WFD and the HDs. Based on our results, we argue that there is a significant gap of coordination and synergies between the implementation of EU regulations in Greece, which further hamper the efficiency of the measures and thus reduces the likelihood of Greek freshwaters to achieve the "good" ecological status. Hence, we urge policy makers to revisit the river basin management planning and place special emphasis on protected areas to resolve any conflicts or lack of compliance between the EU directives.

Author Contributions: Conceptualization, K.S. and A.O.; methodology, K.S. and A.O.; data analysis, K.S. and A.O.; visualization, K.S., A.O. and E.D.; writing-original draft preparation, K.S. and A.O.; writing-review and editing, K.S., A.O., M.S., E.D. and N.T.S.; funding acquisition, M.S., E.D. and N.T.S. All authors have read and agreed to the published version of the manuscript.

Funding: This work has been funded by the National Monitoring Programme of the water quality status of the Greek surface waters, supported by the projects with MIS: 5001676, 371010, 371138, $371140,371144,371145$, which have been financed by the Hellenic Republic, the European Regional Development Fund (ERDF) \& Cohesion Fund (CF).

Institutional Review Board Statement: Not applicable.

Informed Consent Statement: Not applicable.

Acknowledgments: We thank the three anonymous reviewers for their invaluable comments and recommendations that helped us improve our article.

Conflicts of Interest: The authors declare no conflict of interest.

\section{References}

1. Gleick, P.H. Water resources. In Encyclopedia of Climate and Weather; Schneider, S., Ed.; Oxford University Press: New York, NY, USA, 1996; pp. 817-823.

2. Garcia-Moreno, J.; Harrison, I.J.; Dudgeon, D.; Clausnitzer, V.; Darwall, W.; Farrell, T.; Savy, C.; Tockner, K.; Tubbs, N. Sustaining freshwater biodiversity in the Anthropocene. In The Global Water System in the Anthropocene: Challenges for Science and Governance; Springer International Publishing: New York, NY, USA, 2014; pp. 247-270, ISBN 9783319075488.

3. Reid, A.J.; Carlson, A.K.; Creed, I.F.; Eliason, E.J.; Gell, P.A.; Johnson, P.T.J.; Kidd, K.A.; MacCormack, T.J.; Olden, J.D.; Ormerod, S.J.; et al. Emerging threats and persistent conservation challenges for freshwater biodiversity. Biol. Rev. 2019, 94, 849-873. [CrossRef]

4. Grizzetti, B.; Pistocchi, A.; Liquete, C.; Udias, A.; Bouraoui, F.; Bund, W. Van de Human pressures and ecological status of European rivers. Sci. Rep. 2017, 2017, 1-11. [CrossRef]

5. European Commission Council Directive of 2 April 1979 on the conservation of wild birds. Off. J. Eur. Communities 1979, 103, 18. [CrossRef]

6. European Commission. Directive 2009/28/EC of the European Parliament and of the Council of 23 April 2009 on the promotion of the use of energy from renewable sources and amending and subsequently repealing Directives 2001/77/EC and 2003/30/EC. Off. J. Eur. Union 2009, 140, 46.

7. Janauer, G.A.; Albrecht, J.; Stratmann, L. Synergies and conflicts between water framework directive and natura 2000: Legal requirements, technical guidance and experiences from practice. GeoPlanet Earth Planet. Sci. 2015, 15, 9-29. [CrossRef]

8. Skoulikidis, N.T.; Karaouzas, I.; Amaxidis, Y.; Lazaridou, M.; Zessner, M. Impact of EU Environmental Policy Implementation on the Quality and Status of Greek Rivers. Water 2021, 13, 1858. [CrossRef]

9. Herbert, M.E.; Mcintyre, P.B.; Doran, P.J.; Allan, J.D.; Abell, R. Terrestrial reserve networks do not adequately represent aquatic ecosystems. Conserv. Biol. 2010, 24, 1002-1011. [CrossRef]

10. Van Rees, C.B.; Waylen, K.A.; Schmidt-Kloiber, A.; Thackeray, S.J.; Kalinkat, G.; Martens, K.; Domisch, S.; Lillebø, A.I.; Hermoso, V.; Grossart, H.P.; et al. Safeguarding freshwater life beyond 2020: Recommendations for the new global biodiversity framework from the European experience. Conserv. Lett. 2020, 14, 1-17. [CrossRef]

11. Spiliopoulou, K.; Dimitrakopoulos, P.G.; Brooks, T.M.; Kelaidi, G.; Paragamian, K.; Kati, V.; Oikonomou, A.; Vavylis, D.; Trigas, P.; Lymberakis, P.; et al. The Natura 2000 network and the ranges of threatened species in Greece. Biodivers. Conserv. 2021, 30, 945-961. [CrossRef] 
12. Coates, D. Strategic plan for biodiversity (2011-2020) and the aichi biodiversity targets. In The Wetland Book; Springer: Dordrecht, The Netherlands, 2016; pp. 1-7.

13. Secretariat of the Convention on Biological Diversity. Global Biodiversity Outlook 2; Secretariat of the Convention on Biological Diversity: Montreal, QC, Canada, 2006.

14. The Intergovernmental Science-Policy Platform on Biodiversity and Ecosystem Services. Summary for Policymakers of the Global Assessment Report on Biodiversity and Ecosystem Services of the Intergovernmental Science-Policy Platform on Biodiversity and Ecosystem Services; IPBES Secretariat: Bonn, Germany, 2019.

15. CBD. Convention on Biological Diversity. Available online: https://www.cbd.int/conferences/post2020 (accessed on 22 April 2021).

16. European Commission. European Commission Directive of the European Parliament and of the Council 2000/60/EC. Establishing a Framework for Community Action in the Field of Water Policy. Off. J. Eur. Parliam. 2000, L327, 1-82.

17. European Union. The EU Biodiversity Strategy to 2020; European Union: Brussels, Belgium, 2011. [CrossRef]

18. European Commission. European Commission Links between the Water Framework Directive and Nature Directives: Frequently Asked Questions; European Commission: Brussels, Belgium, 2011.

19. Sundseth, K. Working towards Creating Synergies between the WFD, MSFD and the Habitats and Birds Directives: Selected Case Studies; Ecosystems LTD/N2K GROUP. October 2015. Available online: https:/ / ec.europa.eu/environment/nature/natura2000/ management/docs/Compilation\%20WFD\%20MSFD\%20HBD.pdf (accessed on 15 June 2021).

20. European Environment Agency. Management Effectiveness in the EU's Natura 2000 Network of Protected Areas; European Environment Agency: København, Denmark, 2020.

21. Piggott, J.J.; Townsend, C.R.; Matthaei, C.D. Reconceptualizing synergism and antagonism among multiple stressors. Ecol. Evol. 2015, 5, 1538-1547. [CrossRef] [PubMed]

22. MoEE. 5th National Report to the Convention on Biological Diversity. 2016. Available online: https://www.cbd.int/doc/world/ gr/gr-nr-05-en.pdf (accessed on 15 June 2021).

23. Oikonomou, A.; Stefanidis, K. $\alpha$ - and $\beta$-Diversity Patterns of Macrophytes and Freshwater Fishes are Driven by Different Factors and Processes in Lakes of the Unexplored Southern Balkan Biodiversity Hotspot. Water 2020, 12, 1984. [CrossRef]

24. Oikonomou, A.; Leprieur, F.; Leonardos, I.D. Biogeography of freshwater fishes of the Balkan Peninsula. Hydrobiologia 2014, 738, 205-220. [CrossRef]

25. OECD. OECD Environmental Performance Reviews: Greece 2020; OECD: Paris, France, 2020; 157p. [CrossRef]

26. Stefanidis, K.; Latsiou, A.; Kouvarda, T.; Lampou, A.; Kalaitzakis, N.; Gritzalis, K.; Dimitriou, E. Disentangling the Main Components of Hydromorphological Modifications at Reach Scale in Rivers of Greece. Hydrology 2020, 7, 22. [CrossRef]

27. Latsiou, A.; Kouvarda, T.; Stefanidis, K.; Papaioannou, G.; Gritzalis, K.; Dimitriou, E. Pressures and Status of the Riparian Vegetation in Greek Rivers: Overview and Preliminary Assessment. Hydrology 2021, 8, 55. [CrossRef]

28. Grilli, L.; Rampichini, C. Ordered logit model. In Encyclopedia of Quality of Life and Well-Being Research; Michalos, A.C., Ed.; Springer: Dordrecht, The Netherlands, 2014; pp. 4510-4513. ISBN 978-94-007-0753-5.

29. R Core Team. R: A Language and Environment for Statistical Computing; R Core Team: Vienna, Austria, 2020.

30. Trein, P.; Biesbroek, R.; Bolognesi, T.; Cejudo, G.M.; Duffy, R.; Hustedt, T.; Meyer, I. Policy Coordination and Integration: A Research Agenda. Public Adm. Rev. 2021, 81, 973-977. [CrossRef]

31. Adam, C.; Steinebach, Y.; Knill, C. Neglected challenges to evidence-based policy-making: The problem of policy accumulation. Policy Sci. 2018, 51, 269-290. [CrossRef]

32. Bolognesi, T.; Nahrath, S. Environmental Governance Dynamics: Some Micro Foundations of Macro Failures. Ecol. Econ. 2020, 170, 106555. [CrossRef]

33. Bolognesi, T.; Gerlak, A.K.; Giuliani, G. Explaining and measuring social-ecological pathways: The case of global changes and water security. Sustainability 2018, 10, 4378. [CrossRef]

34. Lemm, J.U.; Venohr, M.; Globevnik, L.; Stefanidis, K.; Panagopoulos, Y.; van Gils, J.; Posthuma, L.; Kristensen, P.; Feld, C.K.; Mahnkopf, J.; et al. Multiple stressors determine river ecological status at the European scale: Towards an integrated understanding of river status deterioration. Glob. Chang. Biol. 2021, 20, 1962-1975. [CrossRef]

35. Hale, R.; Piggott, J.J.; Swearer, S.E. Describing and understanding behavioral responses to multiple stressors and multiple stimuli. Ecol. Evol. 2017, 7, 38-47. [CrossRef]

36. Birk, S.; Chapman, D.; Carvalho, L.; Spears, B.M.; Andersen, H.E.; Argillier, C.; Auer, S.; Baattrup-Pedersen, A.; Banin, L.; Beklioğlu, M.; et al. Impacts of multiple stressors on freshwater biota across spatial scales and ecosystems. Nat. Ecol. Evol. 2020, 4, 1060-1068. [CrossRef] [PubMed]

37. Spears, B.M.; Chapman, D.; Carvalho, L.; Rankinen, K.; Stefanidis, K.; Ives, S.; Vuorio, K.; Birk, S. Assessing multiple stressor effects to inform climate change management responses in three European catchments. Inland Waters 2021, 1-13. [CrossRef]

38. Piggott, J.J.; Townsend, C.R.; Matthaei, C.D. Climate warming and agricultural stressors interact to determine stream macroinvertebrate community dynamics. Glob. Chang. Biol. 2015, 21, 1887-1906. [CrossRef]

39. Spears, B.M.; Chapman, D.S.; Carvalho, L.; Feld, C.K.; Gessner, M.O.; Piggott, J.J.; Banin, L.F.; Gutiérrez-Cánovas, C.; Solheim, A.L.; Richardson, J.A.; et al. Making waves. Bridging theory and practice towards multiple stressor management in freshwater ecosystems. Water Res. 2021, 196, 116981. [CrossRef] 
40. Calapez, A.R.; Serra, S.R.Q.; Santos, J.M.; Branco, P.; Ferreira, T.; Hein, T.; Brito, A.G.; Feio, M.J. The effect of hypoxia and flow decrease in macroinvertebrate functional responses: A trait-based approach to multiple-stressors in mesocosms. Sci. Total Environ. 2018, 637-638, 647-656. [CrossRef]

41. Carvalho, L.; Mackay, E.B.; Cardoso, A.C.; Baattrup-Pedersen, A.; Birk, S.; Blackstock, K.L.; Borics, G.; Borja, A.; Feld, C.K.; Ferreira, M.T.; et al. Protecting and restoring Europe's waters: An analysis of the future development needs of the Water Framework Directive. Sci. Total Environ. 2019, 658, 1228-1238. [CrossRef]

42. Stefanidis, K.; Panagopoulos, Y.; Mimikou, M. Impact assessment of agricultural driven stressors on benthic macroinvertebrates using simulated data. Sci. Total Environ. 2016, 540, 32-42. [CrossRef]

43. Stefanidis, K.; Papaioannou, G.; Markogianni, V.; Dimitriou, E. Water Quality and Hydromorphological Variability in Greek Rivers: A Nationwide Assessment with Implications for Management. Water 2019, 11, 1680. [CrossRef]

44. Smeti, E.; von Schiller, D.; Karaouzas, I.; Laschou, S.; Vardakas, L.; Sabater, S.; Tornés, E.; Monllor-Alcaraz, L.S.; Guillem-Argiles, N.; Martinez, E.; et al. Multiple stressor effects on biodiversity and ecosystem functioning in a Mediterranean temporary river. Sci. Total Environ. 2019, 647, 1179-1187. [CrossRef] [PubMed]

45. European Commission. The Environmental Implementation Review 2019 GREECE; Directorate-General for Environment, European Commission: Brussels, Belgium, 2019.

46. Loga, M.; Wierzchołowska-Dziedzic, A.; Martyszunis, A. The problem of water body status misclassification-a Hierarchical Approach. Environ. Monit. Assess. 2018, 190, 1-16. [CrossRef]

47. Snell, M.A.; Barker, P.A.; Surridge, B.W.J.; Benskin, C.M.W.H.; Barber, N.; Reaney, S.M.; Tych, W.; Mindham, D.; Large, A.R.G.; Burke, S.; et al. Strong and recurring seasonality revealed within stream diatom assemblages. Sci. Rep. 2019, 9, 1-7. [CrossRef]

48. Zogaris, S.; Skoulikidis, N.; Dimitriou, E. River and wetland restoration in Greece: Lessons from biodiversity conservation initiatives. Handb. Environ. Chem. 2018, 59, 403-431. [CrossRef]

49. Verdonschot, P.F.M.; Spears, B.M.; Feld, C.K.; Brucet, S.; Keizer-Vlek, H.; Borja, A.; Elliott, M.; Kernan, M.; Johnson, R.K. A comparative review of recovery processes in rivers, lakes, estuarine and coastal waters. Hydrobiologia 2013, 704, 453-474. [CrossRef]

50. Vermaat, J.E.; Wagtendonk, A.J.; Brouwer, R.; Sheremet, O.; Ansink, E.; Brockhoff, T.; Plug, M.; Hellsten, S.; Aroviita, J.; Tylec, L.; et al. Assessing the societal benefits of river restoration using the ecosystem services approach. Hydrobiologia 2016, 769, 121-135. [CrossRef]

51. Haase, P.; Hering, D.; Jähnig, S.C.; Lorenz, A.W.; Sundermann, A. The impact of hydromorphological restoration on river ecological status: A comparison of fish, benthic invertebrates, and macrophytes. Hydrobiologia 2013, 704, 475-488. [CrossRef]

52. MoEE. National Biodiversity Strategy \& Action Plan; Ministry of Environment, Energy \& Climate Change: Athens, Greece, 2014; ISBN 9789607284334.

53. Stefanidis, K.; Sarika, M.; Papastegiadou, E. Exploring environmental predictors of aquatic macrophytes in water-dependent Natura 2000 sites of high conservation value: Results from a long-term study of macrophytes in Greek lakes. Aquat. Conserv. Mar. Freshw. Ecosyst. 2019, 29, 1133-1148. [CrossRef]

54. Weigelhofer, G.; Feldbacher, E.; Trauner, D.; Pölz, E.; Hein, T.; Funk, A. Integrating Conflicting Goals of the EC Water Framework Directive and the EC Habitats Directives into Floodplain Restoration Schemes. Front. Environ. Sci. 2020, 8, 225. [CrossRef]

55. Schröder, N.J.S.; Newig, J.; Watson, N. Bright Spots for Local WFD Implementation Through Collaboration with Nature Conservation Authorities? Water Altern. 2020, 13, 582-617.

56. Beunen, R.; van der Knaap, W.G.M.; Biesbroek, G.R. Implementation and integration of EU environmental directives. Experiences from The Netherlands. Environ. Policy Gov. 2009, 19, 57-69. [CrossRef]

57. Lehtoranta, V.; Louhi, P. Does conservation in Natura 2000 areas promote water quality improvement? Findings from a contingent valuation study on environmental benefits and residents' preferences. Environ. Sci. Policy 2021, 124, 226-234. [CrossRef] 